\title{
Influence of the geographical pattern of foreign trade on the inland distribution of maritime traffic
}

\section{Ticiana Grecco Zanon Moura}

REGIOlab, Department of Applied Economics, University of Oviedo - Avda. del Cristo

S/N, 33006 Oviedo, Spain

Universidade Estadual de Santa Cruz, Rod. Jorge Amado, Km 16, CEP 45662-900, Ilhéus, Brazil

\section{Lorena Garcia-Alonso}

REGIOlab, Department of Applied Economics, University of Oviedo - Avda. del Cristo S/N, 33006 Oviedo, Spain

\section{Ignacio del Rosal}

Department of Applied Economics, University of Oviedo - Avda. del Cristo S/N, 33006 Oviedo, Spain

\begin{abstract}
:
Many papers analyse the role of transport infrastructure in the economic development and competitiveness of regions. However, the literature has paid little attention to the impact of the changing patterns of international trade on the use of the infrastructure. The hypothesis of this work is that the evolution of the geographical pattern of countries' foreign trade influences the inland distribution of maritime traffic and, consequently, the use of the infrastructure. The inter-port distribution of the Spanish exports in 2000 and 2015 was analysed in order to confirm the validity of this hypothesis. To that end, the Spatial Interaction Models approach was adopted. The results suggest that the final destination of the flows does influence the inland distribution of the Spanish container flows and, consequently, that the use of the inland transport infrastructure has evolved in line with the geographical pattern of foreign trade.
\end{abstract}

Keywords: hinterland; inland flows distribution; maritime traffic; port choice; foreign trade; spatial interaction models. 


\section{Introduction}

There is ample literature on the role of the transport sector in trade and competitiveness, both at regional and national levels. Recent relevant examples can be found in Bensassi et al. (2015), Bottasso et al. (2018), Brodzicki et al. (2018), Tiller and Thill (2017) or Tsekeris (2016). The relationship between the transport sector and foreign trade is also studied here, but the perspective of analysis has been reversed. It is well known that the activity of ports depends on the dynamism of their geographical surroundings, as well as on the international relevance of the sea routes in which their facilities are included (Ducruet et al., 2013; Notteboom and Rodrigue, 2007). However, the question addressed here is whether changes in the geographical links of such surroundings with the rest of the world have an impact on the inland distribution of the maritime traffic and, consequently, on the use of the transport infrastructure.

Over the past two decades, Asian economies have been gaining prominence. China and India lead this process, but other neighbouring countries, such Korea or Indonesia, are also increasing their relevance (see Hanson, 2012; O'Neill and Terzim, 2014). Using data from the World Bank (2017), the share of the Asian countries in world GDP (in current dollars) went from $7.2 \%$ in 2000 to $20.7 \%$ in 2015. At the same time, the relative weight of America in world GDP fell from 30.6 to $24.3 \%$ (hereafter, America refers to both North and South America). According to the basic logic of the gravity equation (see, e.g., Head and Mayer, 2014), exports rise in proportion to the economic size of the destination and imports rise in proportion to the economic size of the origin. Thus, the global shift in economic size should be reflected in trade flows. The European Union (EU) foreign trade confirms this eastward shift in trade flows: EU trade with America fell from 33.2 to $26.1 \%$, whereas trade with Asia grew from 38.6 to $47.2 \%$ (Eurostat, 2017).

Seaborne trade is heavily dependent on prevailing economic trends (Valentine et al., 2013). In this sense, the Review of Maritime Transport (UNCTAD, 2017) underlines that the demand for maritime transport services is closely linked to the evolution of the world economy, with Chinese import demand being particularly important for maritime trade. Certainly, the global shipping network has its own configuration rules (Ducruet and Notteboom, 2012) and it tends to maintain stability of its overall architecture (Ducruet, 
2017). However, the economic conditions and trade flows between world regions remain key factors in the deployment of shipping lines (Mengqiao et al., 2015).

With these considerations in mind, our hypothesis is that the considerable changes in international trade and maritime routes may have consequences for the inland distribution of the maritime traffic, which in turn should be reflected in the evolution of the inland corridors of flows. This is in line with Blauwens and Van de Voorde (1988), who analysed the evolution of inland transport as a result of changes in port choice for the Belgian case, and with Cantillo et al. (2018) and Veldman et al. (2013), who concluded that the port choice depends, among others factors, on the port location regarding the flow destination. This is of particular interest to countries (or regions) bordering two seas, as is the case of Spain. Hence, the case study presented in this paper focuses on this country.

A Spatial Interaction Model (SIM) was employed to assess whether the port hinterland configuration does actually vary according to the final destination of the shipments. As repulsion and attraction factors, the province-port travel time and the container throughput of the ports were considered respectively, two variables previously identified as determinant to delimit the scope of the hinterland of the Spanish ports (see Moura et al., 2017). The results show that the proposed approach contributes to explain properly the inland distribution of the maritime traffic and confirms that the final destination of flows is relevant for the hinterland configuration of the seaports.

The conclusions of the paper could be useful for public policy and planning. Our results show that the configuration of hinterlands is influenced by the final destination of the traffic. Therefore, the evolution of the use of the inland transport infrastructure is linked to the evolution of the geographical pattern of foreign trade. This is a factor beyond the control of policy makers, but it can be tracked and, to some extent, predicted.

The remainder of the paper is structured as follows: Section 2 provides a short review of the literature. Section 3 presents a descriptive analysis of the case study. Section 4 shows the model proposed to test the validity of the hypothesis stated. Section 5 gathers together the data sources and the obtained results. Some additional considerations are highlighted in Section 6, and a brief discussion is introduced in Section 7. Section 8, finally, summarises the main conclusions.

\section{Literature review}


The analysis of the port choice is not the aim of this paper. However, this is a closely linked issue, as the configuration (and the evolution) of hinterlands relies on the inland distribution of the maritime traffic, which in turn results from the port choice. In this sense, Talley and $\mathrm{Ng}$ (2018) underline that the determinants of port choice will also settle the choice of the hinterland transport chain.

In general, port choice is considered to be influenced by $\operatorname{cost}^{1}$, location, port operations quality and reputation, handling speed and time, facilities, efficiency/frequency of shipping services and hinterland accessibility. The relevance of these variables differs according to the different port players (shippers, forwarders, shipping companies and terminal operators), although the most cited as determinant of port choice both by shippers and shipping companies are costs, port location and reputation, while frequency of shipping services and intermodal connections are among the least cited (Aronietis et al., 2010). However, Halim et al. (2016) highlighted the port hinterland connectivity as a key determinant for port choice by shippers ${ }^{2}$.

Nowadays, ports are considered as pieces in value-driven logistic chains (Robinson, 2002), thus the determinants of the port choice are now considered to be related to the entire logistic chain in which the port is included as a node (Magala and Sammons, 2008). Ports became pawns in a game (Slack, 1993), and their bargaining power and their influence has been reduced (Meersman et al., 2010) because of the mergers and alliances between large shipping lines, which in some cases also integrate vertically (Notteboom et al., 2017; OECD and International Transport Forum, 2008). Nevertheless, ports continue to play the role of interface between sea and land transportation. Their success depends on their ability to attract traffic from the major economic centres and their inclusion in the main shipping routes (hinterland and foreland connections, respectively). According to Fleming and Hayuth (1994), seaports are still characterised by two spatial qualities with complementary dynamics, centrality and intermediac $y^{3}$, which continue to stand out as factors responsible for the heterogeneity of maritime services and port traffic in recent articles (see, for instance, Guerrero et al., 2015 or Ducruet and Itoh, 2015).

\footnotetext{
${ }^{1}$ Inland transport costs are often the most significant part of the total transport cost (Notteboom and Rodrigue, 2005).

${ }^{2}$ A recent synthesis of the most influential factors for shippers can also be found in Shi and Li (2016).

${ }^{3}$ Centrality is related to the location of ports regarding the traffic generation centres, whereas intermediacy refers to their inclusion in the main maritime routes.
} 
All of the above reinforces the interest of the debate about whether "the ship follows the cargo" or "the cargo follows the ship" (see Notteboom, 2009). Such debate is still on-going, and Berli et al. (2018) highlighted that is still not clear whether the sealand connectivity determines or is determined by port activity. It can be said that the services of the shipping companies contribute to attract traffic from the inland side to the port facilities and, simultaneously, port choice by shipping companies is influenced by the availability of cargo, which is directly determined by the hinterland. In this sense, Hayuth (2007) observed that port choice is increasingly being influenced by landside factors and, more recently, Guerrero et al. (2016) found that the impact of shipping services on the geographical pattern of trade is much less important than that of distance. However, as Lee et al. (2008) illustratively stated, ships can move and ports cannot. From this perspective, ports would depend on shipping companies, which is in line with Ducruet and Itoh (2015), who found that port activity is increasingly explained by shipping routes where the ports are included. In addition, Wilmsmeier et al. (2011) noted that corridors now depend more on strategies of vertical cooperation than on the location of the infrastructure.

It is important to note that the activity of transport service providers (both on the sea and land sides) exists because of the trade demand, i.e. transport demand is a derived demand that reacts to changes in trade looking for a rational integration of sea and land segments of traffic flows (Robinson, 2002). According to this, Guerrero et al. (2015) found that maritime transport supply depends to a large extent on the hinterland and highlighted that the maritime services vary as a function of the foreland.

The aim of this paper is not to delve deeper into the analysis of the relevance of the determining variables of port choice, but to study whether the final destination of flows influences the inland distribution of maritime traffic (which certainly results from the port choice). For this purpose, the following case study has been carried out.

\section{Descriptive analysis}

The geographical pattern of the Spanish foreign trade follows the same trends observed internationally, i.e. Spanish flows have experienced an eastward shift. Figure 1 shows the evolution of the Asian and American shares of the Spanish trade (imports plus 
exports) for the period 2000-2015. The Asian share was already higher than the American share at the beginning of the study period (42 vs. $40.3 \%$ ), but at the end of the period the difference between both shares was 28.4 percentage points.

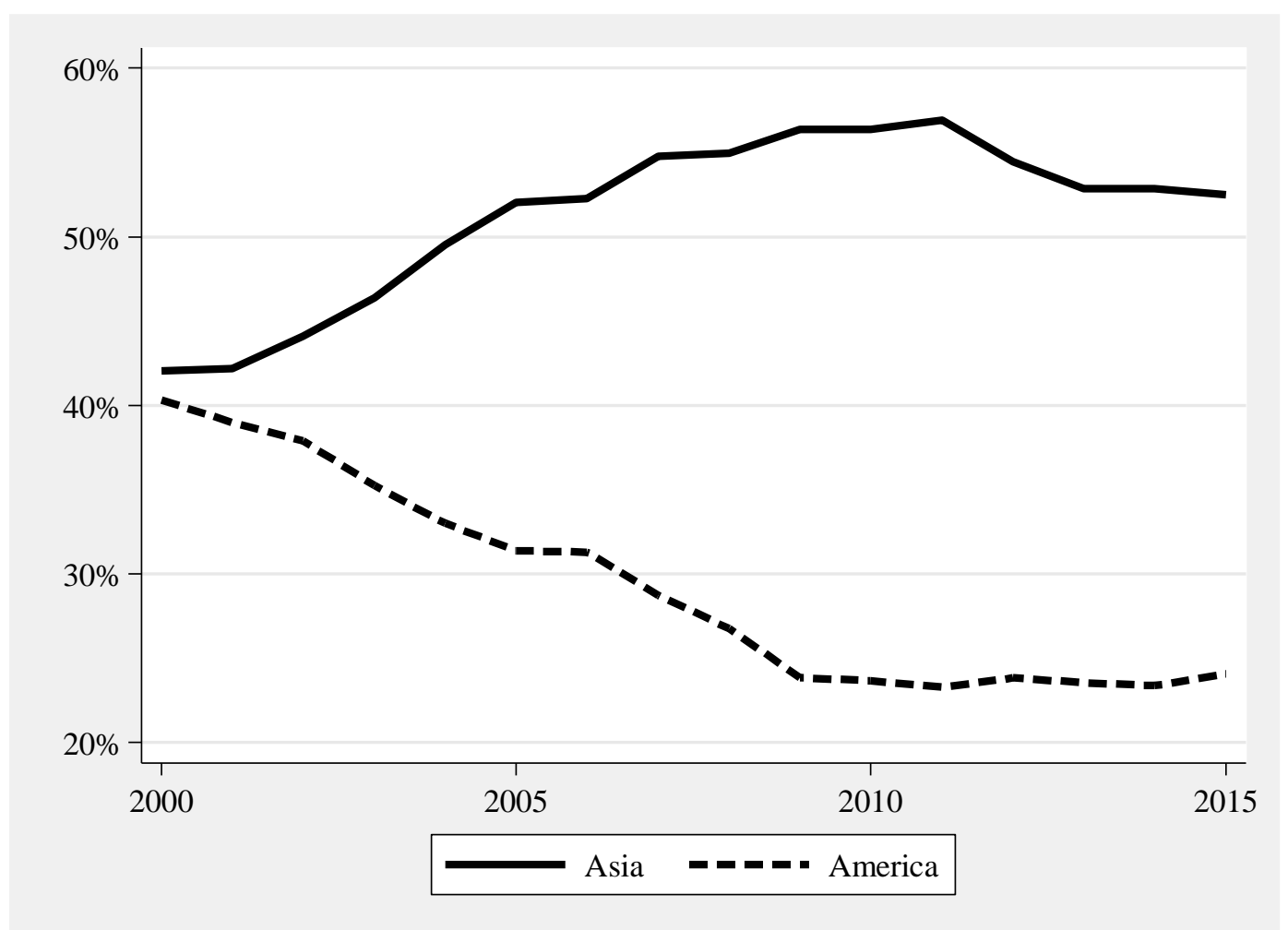

Figure 1. Evolution of the share of Spanish container flows with America and Asia (2000-2015)

Source: authors' own elaboration based on data from the Foreign Trade Statistics of the Customs and Excise Duties Department of the Spanish Tax Agency (2017).

To appreciate whether this evolution in the geographical pattern of the Spanish trade has had consequences for the inland distribution of the freight flows, it is necessary to observe what has happened at the provincial level (NUTS 3$)^{5}$. For this purpose, Figure 2 shows the change in American trade share plotted versus the change in the Asian trade share for the 47 Spanish peninsular provinces. Each province is represented with a circle proportional to its share of Spanish trade. As can be seen, the majority of the provinces (and the most important in trade generation) are situated in the fourth quadrant, showing an eastward shift in the trade flows.

\footnotetext{
${ }^{4}$ So long as the analysis is focused on deep-sea traffic, intra-EU maritime traffic is excluded. Moreover, more than three-quarters of the Spanish containerised deep-sea traffic is linked with Asia and America, this share remaining quite stable during the period of the sample. In the rest of the paper containerised flows with Asia and America will be analysed.

${ }^{5}$ The Balearic and Canary Islands, as well as the autonomous cities of Ceuta and Melilla, are excluded from the analysis.
} 


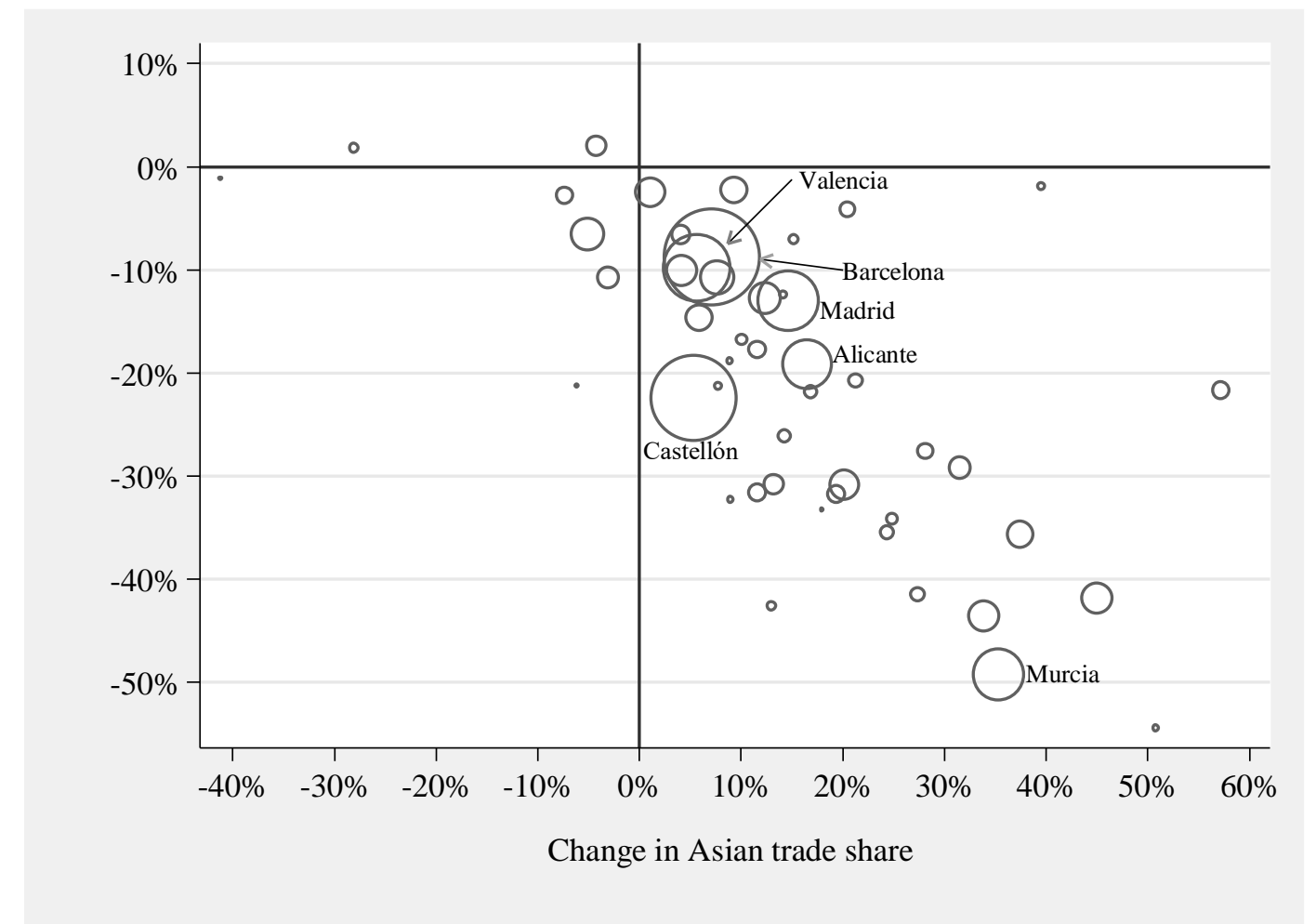

Figure 2. Change in American and Asian trade shares by province (2000-2015). Source: authors' own elaboration based on data from the Foreign Trade Statistics of the Customs and Excise Duties Department of the Spanish Tax Agency (2017).

The analysis of the evolution of the hinterland was carried out regarding the export flows. The seaports considered here are Barcelona, Bilbao and Valencia, which represent a sample-period average of $76.5 \%$ of Spanish container traffic with America and Asia. These ports have been chosen because they compete for the national traffic generated in the northeast peninsular quadrant, which is also where the bulk of the maritime flows is originated (adding Madrid) ${ }^{6}$. The ports of Barcelona and Valencia, specialised in deepsea cargo, are located on the Mediterranean coast and have experienced an expansion both in terms of activity and hinterland scope during the period analysed. Meanwhile, the hinterland scope of the port of Bilbao has been reduced despite having experienced an

\footnotetext{
${ }^{6}$ These seaports, together with Algeciras, are the main peninsula container ports. However, Algeciras was omitted because its traffic is mainly transhipment traffic, which causes it to move a volume of national freight notably lower than the rest. Furthermore, it was also omitted because the geographical scope of its hinterland is much more limited, stable and much less contestable for the rest of the ports (see Garcia-Alonso et al., 2017, 2016 and Moura et al., 2017). Arguably, the characteristics of the port of Algeciras make it equally suitable for channelling traffic from its traditional hinterland to both America and Asia.

The Portuguese ports were also omitted because the traffic channelled through them is negligible compared with the overall Spanish traffic, geographically concentrated along the Mediterranean corridor, the north-eastern corner and Madrid. In the same way, the Portuguese flows were not considered because they are also negligible for the Spanish ports considered. A recent article about the Portuguese ports and their poor hinterland capture in Spain can be found in Santos and Soares (2017).
} 
increase in traffic (but not in share). This port is specialised in short-sea and feeder traffic from the northern range ports of Europe (Monios, 2011).

Table 1 shows the share of each destination taking into account only the Spanish containerised exports channelled to America and $\mathrm{Asia}^{7}$. As can be seen, the flows were balanced in 2000 in the ports of Barcelona and Valencia, but not in Bilbao. At the end of the period, the maritime flows to America accounted for only a third in Mediterranean ports but continued to be predominant in Bilbao. This indicates that the increased ties with the Asian countries have had a greater impact on the ports located in the Mediterranean region.

Table 1. Share of Spanish containerised exports to America and Asia by port

\begin{tabular}{lrr|rc}
\hline & \multicolumn{2}{c|}{$\mathbf{2 0 0 0}$} & \multicolumn{2}{c}{$\mathbf{2 0 1 5}$} \\
\hline & America & Asia & America & Asia \\
Barcelona & $46 \%$ & $54 \%$ & $29 \%$ & $71 \%$ \\
Bilbao & $81 \%$ & $19 \%$ & $63 \%$ & $37 \%$ \\
Valencia & $50 \%$ & $50 \%$ & $33 \%$ & $67 \%$ \\
\hline
\end{tabular}

Source: authors' own elaboration based on data from the Foreign Trade Statistics of the Customs and Excise Duties Department of the Spanish Tax Agency (2017).

However, although these findings are relevant, they do not indicate if the inland distribution of the maritime traffic has experienced any change. This fact can be seen in Figure $3^{8}$. Although the set of the provinces that generate the bulk of exports remains the same, the province-port ties have changed. In particular: i) the hinterland of the port of Barcelona experienced a considerable expansion and its share grew notably; ii) the port of Bilbao reduced both its relevance and its hinterland; and iii) the port of Valencia, despite consolidating its broad hinterland, lost traffic share, as can be seen in Table 2.

\begin{tabular}{ll}
\hline 2000 & 2015 \\
\hline & Barcelona
\end{tabular}

\footnotetext{
${ }^{7}$ The customs data used in the paper concerns Spanish container flows. Thus, unlike shipping and port statistics, our data do not include transhipments.

${ }^{8}$ The legend intervals were defined following Yang et al. (2016).
} 

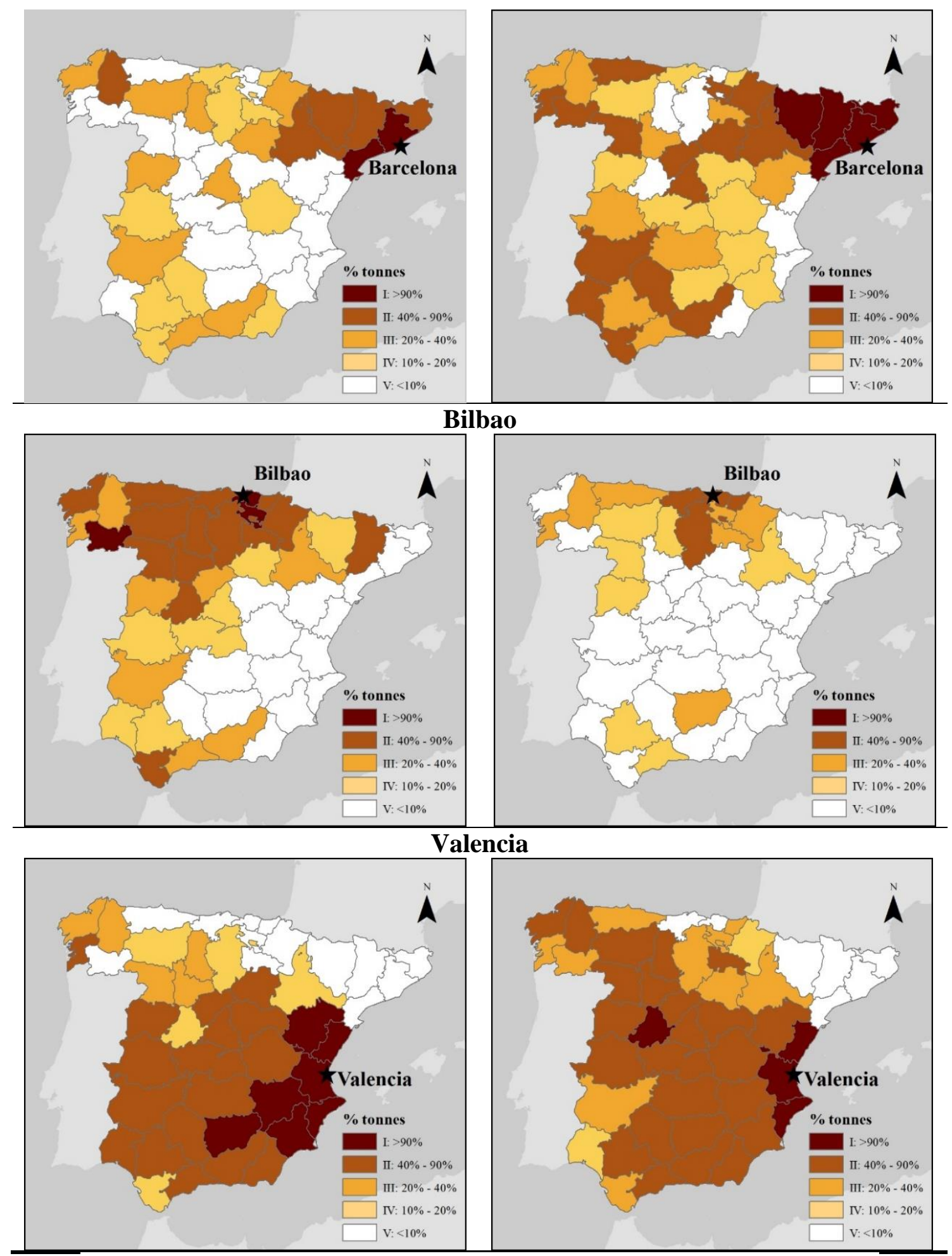

Figure 3. Port share in the provincial export flows (in tonnes) (2000-2015).

Source: authors' own elaboration based on data from the Foreign Trade Statistics of the Customs and Excise Duties Department of the Spanish Tax Agency (2017)

Table 2. Changes in port share by destination

\begin{tabular}{lcc|ccc}
\hline \multicolumn{3}{c|}{ America } & \multicolumn{3}{c}{ Asia } \\
\hline Barcelona & Bilbao & Valencia & Barcelona & Bilbao & Valencia \\
\hline
\end{tabular}




\begin{tabular}{llll|lll}
\cline { 2 - 6 } $\mathbf{2 0 0 0}$ & $22.05 \%$ & $20.84 \%$ & $57.11 \%$ & $29.70 \%$ & $5.60 \%$ & $64.80 \%$ \\
\hline $\mathbf{2 0 1 5}$ & $33.92 \%$ & $16.38 \%$ & $49.69 \%$ & $43.00 \%$ & $5.00 \%$ & $52.10 \%$ \\
\hline
\end{tabular}

Source: authors' own elaboration based on data from the Foreign Trade Statistics of the Customs and Excise Duties Department of the Spanish Tax Agency (2017)

In short, all the above seems to indicate that the port location regarding the flows destination may have some influence on port choice. If this assumption is true, the explanatory capacity of the determining variables for the inland distribution of the maritime traffic should vary according to this fact. To confirm this, we propose a Spatial Interaction Model to carry out the analysis.

\section{Methodological proposal}

According to Lagoudis et al. (2017), port choice is one of the issues of increasing interest to researchers. It has been analysed from different theoretical frameworks, and Discrete Choice Modelling (DCM) is one of the most frequent (see Paixao Casaca et al., 2010). Martínez Moya and Feo Valero (2016) have also found that most of the articles analysing port choice from the Discrete Choice Theory perspective propose Multinomial Logit Models (MNL). Nevertheless, the Spatial Interaction Model (SIM) approach ${ }^{9}$ is more suitable when working with aggregate data ${ }^{10}$ (Roy, 2004), as in this case. As additional advantages of these models, Kerkman et al. (2017) have highlighted that they allow to take into account simultaneously spatial characteristics and characteristics of the transport chain, and Merkel (2017) has emphasised that this approach allows to use distance as a proxy for the unobserved effects ${ }^{11}$ derived from the interdependence existing between the port facilities.

The SIM has been increasingly used within the scope of Regional Science ${ }^{12}$, although not so much in the branch of Transport Economics, and much less in the literature on the analysis of the inland distribution of maritime traffic. To the best of our knowledge, the first authors to deal with it were Debrie and Guerrero (2008). They have

\footnotetext{
${ }^{9}$ Wilson (1971) put forward the SIM by adding a theoretical extension to the traditional gravity model (Roy, 2004; Yano, 1993). A theoretical comparison of DCM and SIM methodologies can be found in Anas (1983), where it is confirmed that they have a similar structure.

${ }^{10}$ The lack of disaggregated data is an additional problem when analysing the spatial distribution of the maritime flows (Ducruet et al., 2013).

${ }^{11}$ Anderson and van Wincoop (2004) lengthily discussed the difficulty of measuring and inferring trade costs, mainly due to the lack of disaggregate data, thus distance is the widely used proxy for trade frictions.

${ }^{12}$ See, among others, Lesage and Polasek (2008). Llano et al. (2010) and Alamá-Sabater et al. (2015) are examples of this methodology applied to the Spanish case.
} 
observed that distance is an important variable in explaining freight distribution in France. Later, Ferrari et al. (2011) analysed the rivalry between the Ligurian ports and those of Northern Europe, concluding that distance is not the only determinant to define the distribution of flows. Later still, Guerrero (2014) concluded that the friction of the distance varies according to the type of merchandise, although the container flows are the least sensitive to its influence. More recently, Guerrero et al. (2016) also applied a SIM including distance and frequency of shipping services as variables to explain the flows between coastal countries, distinguishing by sectors. Tiller and Thill (2017) employed a reverse doubly constrained SIM to verify, measure and compare the degree of trade impedance in South American exports. Finally, Moura et al. (2017) used an origin constrained model as a basis to develop a tool to delimit the hinterland of ports in Spain.

In this paper, we propose an origin-constrained panel SIM to test if the parameters of the variables vary according to both the final destination of shipments (America or Asia) and over the years. This segmentation of flows concerning their destination is in line with Wilson (1971), who suggested that this is a proper approach to verify the existence of different selection behaviours.

The variables commonly selected as proxies for attracting and deterrent factors are size and distance (see Brodzicki et al., 2018). According to this common approach, the variables considered here are the container port throughput (attractiveness factor) and the province-port travel time (repulsion factor). On the one hand, the use of container throughput is compatible with the assumption that the attraction of a destination increases with its mass. Its parameter is therefore interpreted according to the principle of agglomeration, which means that larger destinations are disproportionately more attractive than smaller destinations (Spiekermann et al., 2015). Moreover, container throughput is often used in this field because, as Meersman et al. (2010) argued, container traffic is a good measure of port performance and competitiveness. Additionally, Kashiha et al. (2016) found that port size is highly correlated with port connectivity.

On the other hand, distance is a variable frequently used to study the scope of the hinterland of ports, despite sometimes being controversial (Tongzon, 2009). Shi and Li (2016) have recently highlighted that the regional economy has an increasingly significant role in the development of the hinterland of ports, again underlining the importance of this variable. We follow this approach, although it must be pointed out that 
distance is being progressively replaced by travel time as a proxy for transport costs (Hesse and Rodrigue, 2004; Kerkman et al., 2017) given that the improvements made in infrastructure, as well as the technological advances, cause the friction of the distance to vary over time (Rodrigue, 2012). Hence, the model proposed is (1):

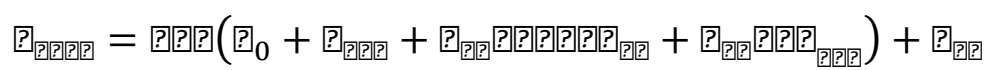

Where:

$F_{i j c t}=$ outflow from province $i$ channelled through port $j$ towards continent $c$ in year $t$;

$\beta_{0}=$ the constant;

$\mu_{i c t}=$ fixed effect of province $i$ by continent $c$ and year $t$;

$\gamma_{c t}=$ parameter measuring the sensitivity of flows to Cont $t_{j t}$;

Cont $_{j t}=$ container throughput of port $j$ in year $t$;

$\lambda_{c t}=$ parameter measuring the sensitivity of flows to $T_{i j t}$;

$T_{i j t}=$ travel time from province $i$ to port $j$ in year $t$;

$\varepsilon_{i c}=$ clustered errors at province-continent $(i-c)$ pair level.

The estimation of the parameters $\left(\gamma_{c t}, \lambda_{c t}\right)$ in (1) follows the approach of Flowerdew and Aitkin (1982), who assert that a Poisson distribution model is applicable when the dependent variable results from a discrete choice probabilistic process ${ }^{13}$. In this particular case, the mean of the dependent variable $\left(F_{i j c t}\right)$ is a function (linked logarithmically) of the independent variables, and the Iteratively Reweighted Least Squares (IRLS) method is recommended to provide the maximum likelihood estimates of the parameters.

Following this method, although the parameters are robust and consistent, they are not necessarily efficient (Krisztin and Fischer, 2015). Therefore, special attention should be paid to the standard errors and the overall goodness-of-fit of the model (see Baxter 1985; Cameron and Triverdi, 2013; Flowerdew and Aitkin, 1982) because the Poisson distribution assumes that the variance of the observations is equal to its average. This assumption is very restrictive since, in general: i) the population is very heterogeneous, thus the data can provide very extreme values (Baxter, 1985; Zeileis, 2004); and ii) the selections involve more than one specific individual or product (Flowerdew and Aitkin, 1982). When analysing the inland distribution of the maritime traffic, both circumstances take place: i) the volume/type of freight can vary significantly by container; and ii) there are different stakeholders involved in port choice (see, for instance, Meersman et al. (2010) or Sanchez et al. (2011)).

13 Wilson entropy-maximising and Poisson-based models, although they were created in different contexts and apparently have diverse structures, are statistically identical (Flowerdew and Lovett, 1988; Yano, 1993). 


\section{Data and results}

\subsection{Data sources}

As stated above, the empirical analysis addressed in this paper is focused on the Spanish containerised exports channelled towards America and Asia through the ports of Barcelona, Bilbao and Valencia. Therefore, the origins (i) considered were the 47 Spanish peninsular provinces, the destinations $(j)$ were the stated Spanish ports, and flow data was extracted from the Foreign Trade Statistics of the Customs and Excise Duties Department of the Spanish Tax Agency (2017). It is worth noting that this customs database is especially useful for the analysis, as it provides reliable information about the province of origin, gateway port, final destination, mode of transport and container use ${ }^{14}$.

The volume of container traffic of ports was obtained from the Ente Público Puertos del Estado (2017) and the province-port travel time from the European road network (Stelder, 2016) ${ }^{15}$. This data source provides information for 2000 and $2012^{16}$. The source has no more recent data on the road network, but we look at 2015 because it is closer in time and it can be assumed that the province-port travel time has barely improved since then ${ }^{17}$. Finally, the path considered each year for each shipment is the fastest taking into account the ArcGIS network analysis tool.

\subsection{Results}

Table 3 shows the results of the maximum likelihood estimation (IRLS procedure) of model (1). The estimates of the parameters of interest, i.e. the elasticities of export flows with respect to container port throughput $\left(\gamma_{c t}\right)$ and with respect to travel time $\left(\lambda_{c t}\right)$, are displayed for the years 2000, 2012 and 2015, and for the destinations America and Asia. In all cases except one, these estimates have the expected sign and are statistically

\footnotetext{
${ }^{14}$ The inclusion of all these details in a single database is very uncommon in trade and shipping statistics (see Guerrero et al., 2016). A comprehensive analysis of the database used in the paper can be found in Escamilla-Navarro et al. (2010). These authors conclude that this data source is particularly reliable for the analysis of extra-EU maritime traffic and suitable for delimiting the hinterland of ports.

15 The province-port travel time is considered only for road transport because, for the Spanish case, the rail transport to ports is less than $7 \%$ than that of the road transport.

${ }^{16}$ During that period, the road network improvements provided a reduction in province-port travel time of $25 \%$ on average.

17 The assumption is based on the important reduction of infrastructure investment caused by the budget constraints that have taken place in Spain over the last few years.
} 
significant at the 1 percent level, with robust standard errors (Zeileis, 2006, 2004) clustered by province-final destination pair level. The R-squared (computed as the square of the correlation between observed and fitted values) reveals that the overall fit of the model is quite good. The results of Table 3 show that the sensitivity of exports with respect to container throughput and travel time varies according to the final destination, and also that such sensitivity evolves over time.

Table 3. Estimation of parameters

\begin{tabular}{|c|c|c|c|c|c|}
\hline & & America & $\begin{array}{c}\text { Robust } \\
\text { Clustered } \\
\text { S. Error }\end{array}$ & Asia & $\begin{array}{c}\text { Robust } \\
\text { Clustered } \\
\text { S. Error }\end{array}$ \\
\hline \multirow{2}{*}{2000} & Container throughput & -0.24 & 0.17 & $1.89 * * *$ & 0.56 \\
\hline & Travel time & $-1.94 * * *$ & 0.59 & $-1.92 * * *$ & 0.57 \\
\hline \multirow{2}{*}{2012} & Container throughput & $0.49 * * *$ & 0.14 & $0.79 * * *$ & 0.14 \\
\hline & Travel time & $-1.34 * * *$ & 0.36 & $-1.55 * * *$ & 0.35 \\
\hline \multirow{2}{*}{2015} & Container throughput & $0.54 * * *$ & 0.10 & $0.76 * * *$ & 0.15 \\
\hline & Travel time & $-1.22 * * *$ & 0.16 & $-1.16^{* * *}$ & 0.19 \\
\hline \multicolumn{2}{|c|}{ Number of observations } & \multicolumn{4}{|c|}{846} \\
\hline \multicolumn{2}{|c|}{ R-squared } & \multicolumn{4}{|c|}{$96.96 \%$} \\
\hline
\end{tabular}

Regarding America, the container throughput (proxy for connectivity) was not a significant variable in 2000. The shipments to America generated that year in the northwest quadrant of Spain were mainly channelled through Bilbao (see Figure A1 of the Appendix) although its volume of container traffic was three times lower than the rest of the ports ${ }^{18}$. This indicates that when the accessibility circumstances are not good enough, the travel time is key for the port choice. It should also be noted that the traffic generated in provinces located between the ports of Bilbao and Barcelona was mainly channelled through the latter, meaning that when travel time is similar, the port throughput is relevant. Similarly, once accessibility is improved, the container throughput becomes more relevant in the port choice, and its relevance tends to increase as the province-port travel time reduces its explanatory power. These results show that the link

\footnotetext{
${ }^{18}$ The share of the ports of Barcelona, Bilbao and Valencia concerning the Spanish container traffic in 2000 was 19.43 , 6.53 and $21.14 \%$, respectively (Ente Público Puertos del Estado, 2017).
} 
between these two forces (attractiveness and repulsion) is intense. In this particular case, the attractiveness of the bigger facilities was reinforced as a consequence of a reduction of the province-port travel time (centrality); that is, improvements in transport infrastructure can make a place more attractive (Krugman, 1991). This may explain several facts. Firstly, the hinterland of the port of Bilbao was smaller in 2015 than in 2000 in terms of the share of traffic each province channels through it. Secondly, the hinterland of the rest of the ports expanded towards the northwest quadrant. Thirdly, the hinterland of the port of Valencia, the largest in terms of container traffic ${ }^{19}$, was expanded in a greater extent. And fourthly, it can also be seen that the traffic contestability increased (because of the improvement in accessibility): the port of Barcelona reinforced its position in the south-west corner, as did Valencia in the north-east.

Concerning the shipments to Asia, container throughput was already significant in 2000, with a similar influence to that of travel time. Contrary to what happened with America, the value of $\gamma_{c t}$ was reduced (although at the end of the period it was still higher for Asian destinations), underlining that the sensitivity of flows to the explicative variables varies depending on the export destination. In this case, the largest ports are located on the most favourable coast in terms of shipment destination. It could be said that the link with Asia is easier from the Mediterranean ports due to their inclusion in a greater number of routes connecting them to this destination (intermediacy), which reinforces the concentration of services providers. As can be seen in Figure A2 of the Appendix, the port of Barcelona was predominant in the northern third, and Valencia from the centre to the south. In 2012, the explanatory power of the container throughput declines more than the travel time. Arguably, the ports of Barcelona and Bilbao maintain strong links with their nearest provinces despite the fact that the container throughput was already considerably smaller there than in the Valencian port. However, those links were much more important with the port of Barcelona, whose container traffic more than doubled that of Bilbao. This fact continued in 2015, but the explanatory power of the travel time decreased from 2012. The reason is that some provinces located in the northern third of the peninsula strengthened their links with the port of Valencia although the share

${ }^{19}$ In 2015, the share of the ports of Barcelona, Bilbao and Valencia concerning all the Spanish container traffic was 11.75, 4.06 and $32.81 \%$, respectively (Ente Público Puertos del Estado, 2017). 
of the ports of Barcelona and Bilbao concerning container traffic recovered slightly from 2012.

In short, from the results it can be said that Valencia has great potential. When export flows to Asia are reinforced, being located in the centre of the Spanish Mediterranean coast, close to the main centres of consumption/production, and being the most important port, is particularly beneficial. All this potential (centrality and intermediacy) results in a larger hinterland, which reinforces the attractiveness of the port as it allows it to operate as a true gateway (Ducruet et al., 2010). At the same time, Bilbao necessarily loses out due to several factors. First, being the smallest port is particularly unfavourable when shipments evolve in favour of Asian destinations. Second, its location, although apparently suitable for exports destined to America, becomes less attractive when accessibility improves. Third, there are fewer shipping companies offering transport services at this port, thus its connectivity is not so good. And fourth, the north-western quadrant is losing share in traffic generation whereas the north-eastern is reinforcing its position (poorer centrality and intermediacy). This is the reason why Barcelona has a renewed potential.

\section{Additional consideration about the results}

The results show that, in general terms, the estimated parameters contribute to explain the inland distribution of the maritime traffic accurately. We now go a step further and consider the discrepancies at the provincial level. Table A1 of the Appendix shows the existing discrepancies about the provincial share in the traffic of ports (observed minus estimated, expressed as a percentage of the former) for the provinces representing about 90\% of the export flows generation in 2000 (see Figure A3 of the Appendix). Considering all the Spanish peninsular provinces (47), the discrepancies are below $1 \%$ in more than three quarters of the cases (85\%), and between 1 and $2 \%$ in less than $8 \%$. Very few cases (4\%) have a discrepancy of over $5 \%$, and only $3 \%$ of the cases exceed $10 \%$. The more prominent discrepancies concern the port of Barcelona regarding the American destinations in 2000, and the Asian destinations for the provinces of Castellón and Barcelona (in 2000 and 2015 respectively). The provinces of Alava and Vizcaya also present a biased result for the port of Bilbao concerning Asia in 2015. In this last case, 
both provinces constitute the surroundings of the port of Bilbao (indeed, the port is located in the province of Vizcaya), and the errors compensate each other.

Two different types of discrepancies can be found: overestimation (observed share $<$ estimated) and underestimation (observed share > estimated). Following Ferrari et al. (2011), overestimation occurs when the link between the port and its hinterland is weaker than expected, showing that there are still potentialities to be exploited. On the other hand, underestimation suggests that the hinterland is more particularly linked to a specific port than expected; that is, it shows some degree of captivity.

Wilson (1971) highlighted that the sensitivity to travel time depends on income, and it is expected to decrease as income increases. Fotheringham and Webber (1980) added that different spatial opportunities could generate non-stable parameters specific to origin in a regional system, proving that masses and flows are spatially correlated. Concerning this case study, the main discrepancies were for the provinces of Barcelona and Castellón, the two provinces in which the largest volume of maritime exports is generated.

It is clear that the spatial structure of flows is important. This is a phenomenon evaluated in the seminal work of Curry (1972), and later corroborated by the literature over the years (Sheppard et al., 1976; Tiefelsdorf, 2003). These authors highlighted that there is a very close relationship between the spatial (geographical) structure of the analysed system and the spatial interactions, which generates spatial autocorrelation and impacts on the estimations (Griffith and Jones, 1980). Additionally, many authors have found that exporters are clustered by destination. Particularly, Cassey and Schmeiser (2013) further found that this concentration of exporters occurs given firms output and the location of ports, using Russian customs data. More related to our study, Ramos and Moral-Benito (2017) analysed the Spanish export flows and concluded that there are agglomeration economies by destination, justified due to both fixed and variable costs involved in the export process. Based on these findings, a possible explanation for the observed discrepancies can be found in Figure A4 of the Appendix, where a great concentration of export flows to America in 2000 both in Barcelona and Castellón can be seen. For the latter province, the concentration was particularly intense for both destinations that year. Figure A4 of the Appendix also shows that the concentration of export flows to Asia strengthened in 2015. Precisely, discrepancies were more numerous 
for this destination that year because they also stand out for the provinces surrounding the port of Bilbao (Álava, Guipúzcoa and Vizcaya).

Besides the issues just mentioned, the sectoral dimension of Spanish trade must also be taken into account. The Spanish trade pattern has evolved, favouring the exports of wood pulp and plastics in detriment to articles of stone, both towards America and Asia. The province of Barcelona is the main origin of the exports of plastic and wood pulp. It experienced a huge increase in the shipments of plastics to Asia, and an important reinforcement of exports of wood pulp towards both continents, but particularly to Asia. Sectoral considerations can also contribute to explain the discrepancies of the province of Barcelona with the port of Bilbao. Exports of chemical products from Barcelona through the port of Bilbao have increased to all destinations, arguably associated to some economies of scale in this particular sector in the port of Bilbao. Idiosyncratic sectoral considerations can also shed light on the discrepancies of the province of Castellón. This province is highly specialised in articles of stone. Exports of this product have been notably deviated from America to Asia, but also to other destinations (e.g. Africa and Oceania). As the analysis was focused on America and Asia, the particular importance of destinations of the rest of the world for the province of Castellón would contribute to explain the discrepancies shown.

\section{Discussion}

Additional research is needed to assess whether these conclusions could be extrapolated to other countries, such as France or USA, or to a broader context, such as the EU. For instance, concerning the EU case as a whole, the largest and best-connected ports are also those that have grown the most during the analysed period. However, unlike what happens in Spain, these ports are located in the north. This is in line with the obtained results: the container throughput (proxy for connectivity) is particularly important to shipments to Asia, and accessibility is not a problem for the northern ports, as they are closer to the main European production/consumption centres (unlike Bilbao in regard to the main Spanish centres). Nevertheless, it should also be noted that ports located in the Mediterranean region have increased their share (Notteboom, 2017).

Monios et al. (2016) have observed that the centre of gravity of European distribution has shifted slightly to the south-east. This shift favours the increase of 
competition between the Northern and Mediterranean European ports, already anticipated by Notteboom (1997) for the traffic generated in Northern Italy, Switzerland, Southern Germany, Spain and the centre and South of France. Actually, central European shippers tend to choose northern ports to channel their traffic because of their shorter distance to the market, the economies of scale reached at their facilities and their higher level of regional integration, highlighted by Brooks et al. (2010) and Ducruet and Zaidi (2012).

However, despite their poorer centrality, a priori, Mediterranean ports are better located for reaching Asian destinations ${ }^{20}$. Acciaro et al. (2017) and Kramberger et al. (2018) pointed out that better hinterland transport services would enable them to capitalise on that advantage. Following these authors, the best strategy for southern ports to compete with the northern facilities should be based on cooperation ${ }^{21}$. This leads to coo-petition, a term introduced in the port sector by Song (2003). It is a mixture of competition and cooperation which facilitates agreements among ports to build up a stronger position in contestable markets or to develop a common marketing strategy, which could drive growth in total traffic for the port range. The aim is to reach benefits than could otherwise not be reached.

The results of this paper suggest that southern ports would need to reinforce their size (which means attracting more shipping lines services and improving their connectivity) to be able to divert traffic from the ports of the north of the EU, and a strategy of coo-petition could be useful for this purpose. This would have consequences not only in terms of the inter-port competition with the northern ports, but also in relation to the inland corridors within each territory. In this sense, Kashiha et al. (2016) reached two important conclusions: i) shippers from landlocked countries value more highly port efficiency and port connectivity, and ii) the larger the shippers, the more important these port characteristics are, so crossing national borders to reach their facilities becomes less relevant.

\section{Concluding remarks}

The purpose of this paper is to analyse whether the geographical pattern of foreign trade influences the inland distribution of maritime traffic and, therefore, the use of the

\footnotetext{
${ }^{20}$ This is important because the growth of container traffic in Asia is ahead of the global average, particularly in South Asia (Wong, 2016).

${ }^{21}$ A typology of port cooperation activities can be found in Brooks et al. (2010).
} 
transport infrastructure. The Spanish case has been studied in order to test the validity of this hypothesis. The results indicate that the impact of the variables determining the interport distribution of shipments varies depending on the final destination of flows. Therefore, it can be said that the geographical pattern of foreign trade does influence the inland distribution of maritime traffic.

Concerning the Spanish case, several conclusions can be drawn. First, the size and scope of the Spanish ports located along the Mediterranean coast have been reinforced. Second, the impact of the province-port travel time as a deterrent factor is higher than the influence of the port throughput as an element of attraction. Third, the influence of this variable (size/connectivity) is higher for flows destined to Asia, despite having increased for flows destined to America. For this particular destination, the improvement of accessibility has benefited the port of Barcelona in detriment to Bilbao (despite its apparent better location to reach America, its connectivity is not so good). And fourth, and in addition to the port throughput and the province-port travel time, the trade creation in the geographical surroundings of ports is a key issue for the increase of their activity (Barcelona). Regarding this last point, the evolution of the foreign trade pattern can doubly influence as changes could lead both to trade creation and diversion in the surroundings of the ports.

An additional and more general conclusion can be drawn from the analysis carried out. It is well known that the inland distribution of maritime traffic depends on many variables, some of which are beyond the control of the port authorities and policy makers. Among them, one of the most relevant is the design of the maritime lines network; another, focused on here, is the geographical destination of the trade flows. Arguably, the latter is more predictable than the former, especially in the medium/long term. The maritime lines network may depend on the decisions of a handful of stakeholders, whereas world economic trends are well tracked and forecasted. This argument makes the results of this paper more relevant, in the sense that the use of the inland infrastructure is linked to the destination of trade flows. Paying attention to global trade trends may help to avoid overcapacity/congestion of ports and inland corridors, thus improving the efficiency in the allocation of resources and reinforcing the competitiveness of domestic exports. 
The primary contribution of this paper is to reverse the analysis of the relationship between infrastructure and trade. The case study analysed shows that there is a link between the evolution of foreign trade and the use of the inland infrastructure. However, more research is needed to further explore two relevant queries. On the one hand, it would be interesting to repeat the analysis in other geographical areas. On the other hand, it would be desirable to extend the analysis carried out by focusing on, for example, the role of shipping lines and their own reaction to the evolution of international trade. 


\section{References}

Acciaro, M., Bardi, A., Cusano, M.I., Ferrari, C., Tei, A., 2017. Contested port hinterlands: An empirical survey on Adriatic seaports. Case Stud. Transp. Policy 5, 342-350. https://doi.org/10.1016/j.cstp.2017.03.006.

Alamá-Sabater, L., Márquez-Ramos, L., Navarro-Azorín, J.M., Suárez-Burguet, C., 2015. A two-methodology comparison study of a spatial gravity model in the context of interregional trade flows. Appl. Econ. 47, 1481-1493. https://doi.org/10.1080/00036846.2014.997929.

Anas, A., 1983. Discrete Choice Theory, Information Theory and the Multinomial Logit and Gravity Models. Transp. Res. Part B Methodol. 17, 13-23. https://doi.org/10.1016/0191-2615(83)90023-1.

Anderson, J., van Wincoop, E., 2004. Trade Costs. J. Econ. Lit. 27, 691-751. https://doi.org/10.1257/0022051042177649.

Aronietis, R., Van de Voorde, E., Vanelslander, T., 2010. Port Competitiveness Determinants of Selected European Ports in the Containerized Cargo Market, in: IAME Annual Conference Proceedings. Lisboa.

Baxter, M.J., 1985. Quasi-likelihood estimation and diagnostic statistics for spatial interaction models. Environ. Plan. A Policy Pract. 17, 1627-1635. https://doi.org/10.1068/a171627.

Bensassi, S., Márquez-Ramos, L., Martínez-Zarzoso, I., Suárez-Burguet, C., 2015. Relationship between logistics infrastructure and trade: Evidence from Spanish regional exports. Transp. Res. Part A Policy Pract. 72, 47-61. https://doi.org/10.1016/j.tra.2014.11.007.

Berli, J., Bunel, M., Ducruet, C., 2018. Sea-Land Interdependence in the Global Maritime Network: the Case of Australian Port Cities. Networks Spat. Econ. 1-25. https://doi.org/10.1007/s11067-018-9403-4.

Blauwens, G., Van de Voorde, E., 1988. The impact of port choice on inland transportation. Marit. Policy Manag. 15, 127-140.

Bottasso, A., Conti, M., de Sa Porto, P.C., Ferrari, C., Tei, A., 2018. Port infrastructures and trade: Empirical evidence from Brazil. Transp. Res. Part A Policy Pract. 107, 126-139. https://doi.org/10.1016/j.tra.2017.11.013.

Brodzicki, T., Márquez-ramos, L., Umiński, S., 2018. The Investigation into Determinants of Regional Exports Base: Panel Analysis for Spanish and Polish Regions. Entrep. Bus. Econ. Rev. 6, 135-151. https://doi.org/10.15678/EBER.2018.060108.

Brooks, M.R., McCalla, R., Palla, A., van der Lugt, L., 2010. Strategic Cooperation in Peripheral Ports: The Case of Atlantic Canada's Ports. Can. J. Transp. 4, $29-42$.

Cameron, A.C., Triverdi, P.K., 2013. Regression analysis of count data. Cambridge university press.

Cantillo, J., Cantillo, V., Arellana, J., 2018. Modelling with joint choice of ports and countries of origin and destination: application to Colombian ports. Marit. Policy Manag. 1-19. https://doi.org/10.1080/03088839.2018.1440090.

Cassey, A.J., Schmeiser, K.N., 2013. The agglomeration of exporters by destination. Ann. Reg. Sci. 51, 495-513. https://doi.org/10.1007/s00168-012-0538-9

Curry, L., 1972. A spatial analysis of gravity flows. Reg. Stud. 6, 131-147. https://doi.org/10.1016/0966-6923(94)90030-2.

Debrie, J., Guerrero, D., 2008. (Re)spatialiser la question portuaire : pour une lecture géographique des arrière-pays européens. L'esp. géographique 37, 45-56. 
https://doi.org/10.1007/978-3-642-03647-7.

Ducruet, C., 2017. Multilayer dynamics of complex spatial networks: The case of global maritime flows (1977-2008). J. Transp. Geogr. 60, 40-58. https://doi.org/10.1016/j.jtrangeo.2017.02.007.

Ducruet, C., Itoh, H., 2015. Regions and material flows: investigating the regional branching and industry relatedness of port traffics in a global perspective. J. Econ. Geogr. 16, 805-830. https://doi.org/10.1093/jeg/lbv010.

Ducruet, C., Itoh, H., Joly, O., 2013. Ports and the local embedding of commodity flows. Pap. Reg. Sci. 94, 607-627. https://doi.org/10.1111/pirs.12083.

Ducruet, C., Koster, H.R.A., Van der Beek, D.J., 2010. Commodity Variety and Seaport Performance. $\quad$ Reg. Stud. $44, \quad 1221-1240$. https://doi.org/10.1080/00343400903167904.

Ducruet, C., Notteboom, T., 2012. The worldwide maritime network of container shipping: spatial structure and regional dynamics. Glob. Networks 12, 395-423. https://doi.org/10.1111/j.1471-0374.2011.00355.x.

Ducruet, C., Zaidi, F., 2012. Maritime constellations: a complex network approach to shipping and ports. Marit. Policy Manag. 39, 151-168.

Ente Público Puertos del Estado, 2017. Anuario estadístico [WWW Document]. URL http://www.puertos.es (accessed 7.3.17).

Escamilla-Navarro, L., García-Menéndez, L., Pérez-García, E., 2010. Integration of foreign trade and maritime transport statistics in Spain. Marit. Policy Manag. 37, 347-375. https://doi.org/10.1080/03088839.2010.486641.

Eurostat, 2017. Comext database [WWW Document]. URL http://ec.europa.eu/eurostat (accessed 6.5.17).

Ferrari, C., Parola, F., Gattorna, E., 2011. Measuring the quality of port hinterland accessibility: The Ligurian case. Transp. Policy 18, 382-391. https://doi.org/10.1016/j.tranpol.2010.11.002.

Fleming, D.K., Hayuth, Y., 1994. Spatial characteristics of transportation hubs: centrality and intermediacy. J. Transp. Geogr. 2, 3-18. https://doi.org/10.1016/09666923(94)90030-2.

Flowerdew, R., Aitkin, M., 1982. A method of fitting the gravity model based on the poisson distribution. J. Reg. Sci. 22, 191-202. https://doi.org/10.1111/j.14679787.1982.tb00744.x.

Flowerdew, R., Lovett, A., 1988. Fitting Constrained Poisson Regression Models to Interurban Migration Flows. Geogr. Anal. 20, 297-307. https://doi.org/10.1111/j.1538-4632.1988.tb00184.x.

Foreign Trade Statistics of the Customs and Excise Duties Department of the Spanish Tax Agency, 2017. Statistical data [WWW Document]. URL http://www.agenciatributaria.es (accessed 1.3.16).

Fotheringham, A.S., Webber, M.J., 1980. Spatial structure and the parameters of spatial interaction models. Geogr. Anal. 12, 33-46. https://doi.org/10.1111/j.15384632.1980.tb00016.x.

Garcia-Alonso, L., Martinez-Pardo, A., Vallejo-Pinto, J.Á., 2016. Analysis of the spatial development of the hinterland of ports: a case study. Int. J. Shipp. Transp. Logist. 8, 111-128. https://doi.org/10.1504/IJSTL.2016.075007.

Garcia-Alonso, L., Monios, J., Vallejo-Pinto, J.Á., 2017. Port competition through hinterland accessibility: the case of Spain. Marit. Econ. Logist. https://doi.org/10.1057/s41278-017-0085-5. 
Griffith, D.A., Jones, K.G., 1980. Explorations into the relationship between spatial structure and spatial interaction. Environ. Plan. A Econ. Sp. 12, 187-201. https://doi.org/10.1068/a120187.

Guerrero, D., 2014. Deep-sea hinterlands: Some empirical evidence of the spatial impact of containerization. J. Transp. Geogr. 35, 84-94. https://doi.org/10.1016/j.jtrangeo.2014.01.010.

Guerrero, D., Grasland, C., Ducruet, C., 2016. Explaining international trade flows with shipping-based distances, in: Ducruet, C. (Ed.), Maritime Networks: Spatial Structures and Time Dynamics. Routledge, pp. 302-320.

Guerrero, D., Laxe, F.G., Seoane, M.F., Montes, C.P., 2015. A Geographical Analysis of the Relationship Between Inland Accessibility and Maritime Transport Supply. Région et Développement 33-46.

Halim, R.A., Kwakkel, J.H., Tavasszy, L.A., 2016. A strategic model of port-hinterland freight distribution networks. Transp. Res. Part E Logist. Transp. Rev. 95, 368-384. https://doi.org/10.1016/j.tre.2016.05.014.

Hanson, G.H., 2012. The rise of Middle Kingdoms: Emerging Economies in Global Trade. J. Econ. Perspect. 26, 41-63. https://doi.org/10.3386/w17961.

Hayuth, Y., 2007. Globalisation and the Port-Urban Interface: Conflicts and Opportunities, in: Wang, J., Olivier, D., Notteboom, T., Slack, B. (Eds.), Ports, Cities, and Global Supply Chains. Taylor \& Francis Group, New York.

Head, K., Mayer, T., 2014. Gravity Equations: Workhorse, Toolkit, and Cookbook, in: Gopinath, G., Helpman, E., Rogoff, K. (Eds.), Handbook of International Economics, Vol. 4. Elsevier, Amsterdam, pp. 131-195. https://doi.org/10.1016/B978-0-444-54314-1.00003-3.

Hesse, M., Rodrigue, J.-P., 2004. The transport geography of logistic and freight $\begin{array}{lllll}\text { distribution. } & \text { J. } & \text { Transp. } & \text { Geogr. } & 12,\end{array}$ https://doi.org/10.1016/j.jtrangeo.2003.12.004.

Kashiha, M., Thill, J.-C., Depken II, C.A., 2016. Shipping route choice across geographies: Coastal vs. landlocked countries. Transp. Res. Part E Logist. Transp. Rev. 91, 1-14. https://doi.org/10.1016/j.tre.2016.03.012.

Kerkman, K., Martens, K., Meurs, H., 2017. A multilevel spatial interaction model of transit flows incorporating spatial and network autocorrelation. J. Transp. Geogr. 60, 155-166. https://doi.org/10.1016/j.jtrangeo.2017.02.016.

Kramberger, T., Monios, J., Strubelj, G., Rupnik, B., 2018. Using dry ports for port coopetition: the case of Adriatic ports. Int. J. Shipp. Transp. Logist. 10, 18-44. https://doi.org/10.1504/IJSTL.2018.088319.

Krisztin, T., Fischer, M.M., 2015. The Gravity Model for International Trade: Specification and Estimation Issues. Spat. Econ. Anal. 10, 451-470. https://doi.org/10.1080/17421772.2015.1076575.

Krugman, P., 1991. Increasing Returns and Economic Geography. J. Polit. Econ. https://doi.org/10.1086/261763.

Lagoudis, I.N., Theotokas, I., Broumas, D., 2017. A literature review of port competition research. Int. J. Shipp. Transp. Logist. 9, 724-762. https://doi.org/10.1504/IJSTL.2017.10007004.

Lee, S.-W., Song, D.-W., Ducruet, C., 2008. A tale of Asia's world ports: The spatial evolution in global hub port cities. Geoforum 39, 372-385. https://doi.org/10.1016/j.geoforum.2007.07.010.

Lesage, J., Polasek, W., 2008. Incorporating Transportation Network Structure in Spatial 
Econometric Models of Commodity Flows. Spat. Econ. Anal. 3, 225-245. https://doi.org/10.1080/17421770801996672.

Llano, C., Esteban, A., Perez, J., Pulido, A., 2010. Opening the Interregional Trade "'Black Box"”: The C-Intereg Database for the Spanish Economy (1995-2005), Int. Reg. Sci. Rev. https://doi.org/10.1177/0160017610370701.

Magala, M., Sammons, A., 2008. A new approach to port choice modelling. Marit. Econ. Logist. 10, 9-34. https://doi.org/10.1057/palgrave.mel.9100189.

Martínez Moya, J., Feo Valero, M., 2016. Port choice in container market: a literature review. Transp. Rev. 0, 1-22. https://doi.org/10.1080/01441647.2016.1231233

Meersman, H., Van De Voorde, E., Vanelslander, T., 2010. Port Competition Revisited. Rev. Bus. Econ. Lit. 55, 210-233.

Mengqiao, X., Zhenfu, L., Yanlei, S., Xiaoling, Z., Shufei, J., 2015. Evolution of regional inequality in the global shipping network. J. Transp. Geogr. 44, 1-12. https://doi.org/doi.org/10.1016/j.jtrangeo.2015.02.003.

Merkel, A., 2017. Spatial competition and complementarity in European port regions. J. Transp. Geogr. 61, 40-47. https://doi.org/10.1016/j.jtrangeo.2017.04.008.

Monios, J., 2011. The role of inland terminal development in the hinterland access strategies of Spanish ports. Res. Transp. Econ. 33, 59-66. https://doi.org/10.1016/j.retrec.2011.08.007.

Monios, J., Notteboom, T., Wilmsmeier, G., Rodrigue, J.-P., 2016. Competition and complementarity between seaports and hinterlands for locating distribution activities [WWW Document]. Port_Economics. URL http://www.porteconomics.eu/2016/04/16/competition-and-complementaritybetween-seaports-and-hinterlands-for-locating-distribution-activities/ (accessed 1.6.18).

Moura, T.G.Z., Garcia-Alonso, L., Salas-Olmedo, M.H., 2017. Delimiting the scope of the hinterland of ports: proposal and case study. J. Transp. Geogr. 65, 35-43. https://doi.org/10.1016/j.jtrangeo.2017.09.012.

Notteboom, T.E., 2017. Top EU container port regions (2007-2016): the rise of South Europe [WWW Document]. Port_Economics. URL http://www.porteconomics.eu/2017/07/31/portgraphic-top-eu-container-portregions-2007-2016-the-rise-of-south-europe (accessed 1.1.17).

Notteboom, T.E., 2009. Path Dependency and Contigency in the Development of Multiport Gateway Regions and Multi-port Hub Regions, in: Notteboom, T., Ducruet, C., Langen, P. de (Eds.), Ports in Proximity. Ashgate Publishing Company, pp. 55-74.

Notteboom, T.E., 1997. Concentration and load centre development in the European container port system. J. Transp. Geogr. 5, 99-115. https://doi.org/10.1016/S09666923(96)00072-5.

Notteboom, T.E., Parola, F., Satta, G., Pallis, A.A., 2017. The relationship between port choice and terminal involvement of alliance members in container shipping. J. Transp. Geogr. 64, 158-173. https://doi.org/10.1016/j.jtrangeo.2017.09.002.

Notteboom, T.E., Rodrigue, J.-P., 2007. Re-assessing port-hinterland relationships in the context of global supply chains. Ports, Cities, Glob. Supply Chain. 51-66.

Notteboom, T.E., Rodrigue, J.-P., 2005. Port regionalization: towards a new phase in port development. Marit. Policy Manag. 32, 297-313. https://doi.org/10.1080/03088830500139885.

O' Neill, J., Terzim, A., 2014. Changing trade patterns, unchanging European and global governance (No. 02). Bruegel Working Paper. 
OECD, International Transport Forum, 2008. Port Competition and Hinterland Connections: Summary and conclusions (No. 19). Paris. https://doi.org/10.1787/235100656678.

Paixao Casaca, A., Carvalho, S., Oliveira, M., 2010. Port choice in the European short sea shipping market: the view of point of port authorities, in: IAME Annual Conference Proceedings. Lisboa. Lisbon.

Ramos, R., Moral-Benito, E., 2017. Agglomeration by Export Destination: Evidence from Spain. J. Econ. Geogr. 1-32. https://doi.org/10.1093/jeg/lbx038.

Robinson, R., 2002. Ports as elements in value-driven chain systems: the new paradigm. Marit. Policy Manag. 29, 241-255. https://doi.org/10.1080/03088830210132623.

Rodrigue, J.-P., 2012. Supply Chain Management, Logistics Changes and the Concept of Friction, in: Hall, P. V, Hesse, M. (Eds.), Cities, Regions and Flows. Routledge, London.

Roy, J.R., 2004. Spatial Interaction Modelling: a Regional Science Context, Springer. https://doi.org/10.1007/978-3-642-17940-2.

Sanchez, R.J., Ng, A.K.Y., Garcia-Alonso, L., 2011. Port Selection Factors and Attractiveness: The Service Providers' Perspective. Transp. J. 50, 141-161. https://doi.org/10.5325/transportationj.50.2.0141.

Santos, T.A., Soares, C.G., 2017. Development dynamics of the Portuguese range as a multi-port gateway system. J. Transp. Geogr. 60, 178-188. https://doi.org/10.1016/j.jtrangeo.2017.03.003.

Sheppard, E.S., Griffith, D.A., Curry, L., 1976. A final comment on mis-specification and autocorrelation in those gravity parameters. Reg. Stud. 10, 337-339. https://doi.org/10.1080/09595237600185341.

Shi, X., Li, H., 2016. Developing the port hinterland: Different perspectives and their application to Shenzhen Port, China. Res. Transp. Bus. Manag. 19, 42-50. https://doi.org/10.1016/j.rtbm.2016.05.004.

Slack, B., 1993. Pawns in the game: ports in a global transportation system. Growth Change 24, 579-588. https://doi.org/10.1111/j.1468-2257.1993.tb00138.x.

Song, D.-W., 2003. Port co-opetition in concept and practice. Marit. Policy Manag. 30, 29-44. https://doi.org/10.1080/0308883032000051612.

Spiekermann, K., Wegener, M., Kveton, V., Marada, M., Schürmann, C., Biosca, O., Ulied Segui, A., Antikainen, H., Kotavaara, O., Rusanen, J., Bielanska, D., Fiorello, D., Komornicki, T., Rosik, P., Stepniak, M., 2015. TRACC - Transport Accessibility at Regional/Local Scale and Patterns in Europe, European Spatial Planning Observation Network - EspoN.

Stelder, D., 2016. Regional accessibility trends in Europe: Road infrastructure, 19572012. Reg. Stud. 50, 983-995. https://doi.org/10.1080/00343404.2014.952721.

Talley, W.K., Ng, M., 2018. Hinterland transport chains: A behavioral examination approach. Transp. Res. Part E Logist. Transp. Rev. 113, 94-98. https://doi.org/10.1016/j.tre.2018.03.001.

Tiefelsdorf, M., 2003. Misspecifications in interaction model distance decay relations-A Spatial structure effect. J. Geogr. Syst. 5, 25-50. https://doi.org/10.1007/s101090300102.

Tiller, K.C., Thill, J.C., 2017. Spatial patterns of landside trade impedance in containerized South American exports. J. Transp. Geogr. 58, 272-285. https://doi.org/10.1016/j.jtrangeo.2017.01.001.

Tongzon, J.L., 2009. Port choice and freight forwarders. Transp. Res. Part E Logist. 
Transp. Rev. 45, 186-195. https://doi.org/10.1016/j.tre.2008.02.004.

Tsekeris, T., 2016. Domestic transport effects on regional export trade in Greece. Res. Transp. Econ. https://doi.org/10.1016/j.retrec.2016.08.006.

UNCTAD, 2017. Review of Maritime Transport [WWW Document]. URL http://unctad.org/en/Pages/Publications/Review-of-Maritime-Transport(Series).aspx (accessed 3.1.18).

Valentine, V.F., Hassiba, B., Hoffmann, J., 2013. Maritime transport and international seaborne trade. Marit. Policy Manag. 40, 226-242. https://doi.org/10.1080/03088839.2013.782964.

Veldman, S., Garcia-Alonso, L., Vallejo-Pinto, J.Á., 2013. A port choice model with logit models: a case study for the Spanish container trade. Int. J. Shipp. Transp. Logist. 5, 373. https://doi.org/10.1504/IJSTL.2013.055277.

Wilmsmeier, G., Monios, J., Lambert, B., 2011. The directional development of intermodal freight corridors in relation to inland terminals. J. Transp. Geogr. 19, 1379-1386. https://doi.org/10.1016/j.jtrangeo.2011.07.010.

Wilson, A., 1971. A family of spatial interaction models, and associated developments. Environ. Plan. 3, 1-32. https://doi.org/10.1068/a030001.

Wong, A., 2016. Global trends and their impact on the port sector, in: 29th IAPH World Port Conference.

World Bank, 2017. World Bank Open Data [WWW Document]. URL https://data.worldbank.org/ (accessed 6.5.17).

Yang, J., Luo, M., Ji, A., 2016. Analyzing the spatial-temporal evolution of a gateway's hinterland: A case study of Shanghai, China. Transp. Res. Part E Logist. Transp. Rev. 95, 355-367. https://doi.org/10.1016/j.tre.2016.03.015.

Yano, K., 1993. Integration of spatial interaction models: towards general theory of spatial interaction. Geogr. Reports Tokyo Metrop. Univ. 28, 33-78.

Zeileis, A., 2006. Object-oriented Computation of Sandwich Estimators. J. Stat. Softw. $16,1-16$.

Zeileis, A., 2004. Econometric Computing with HC and HAC Covariance Matrix Estimators. J. Stat. Softw. 11, 1-17. https://doi.org/10.18637/jss.v011.i10. 


\section{Appendix}

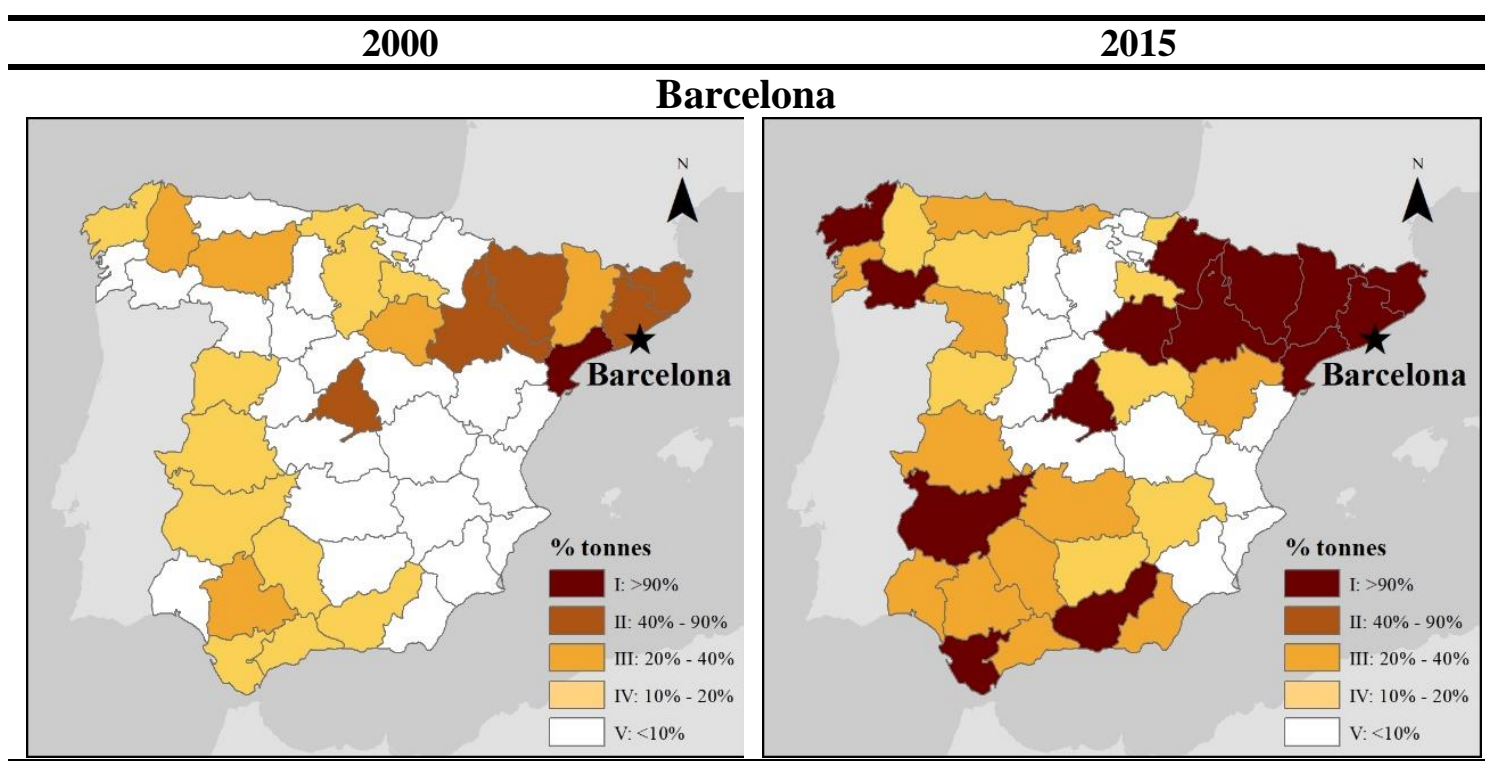

Bilbao

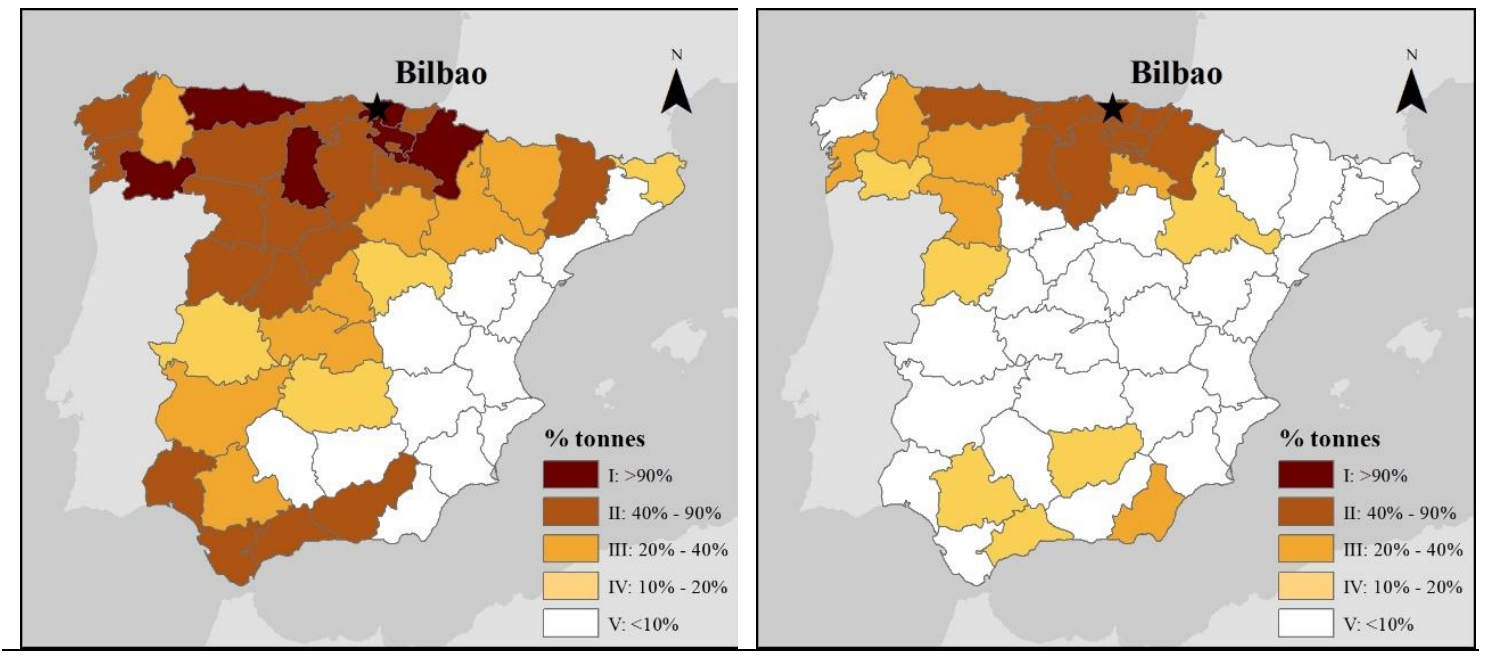

Valencia

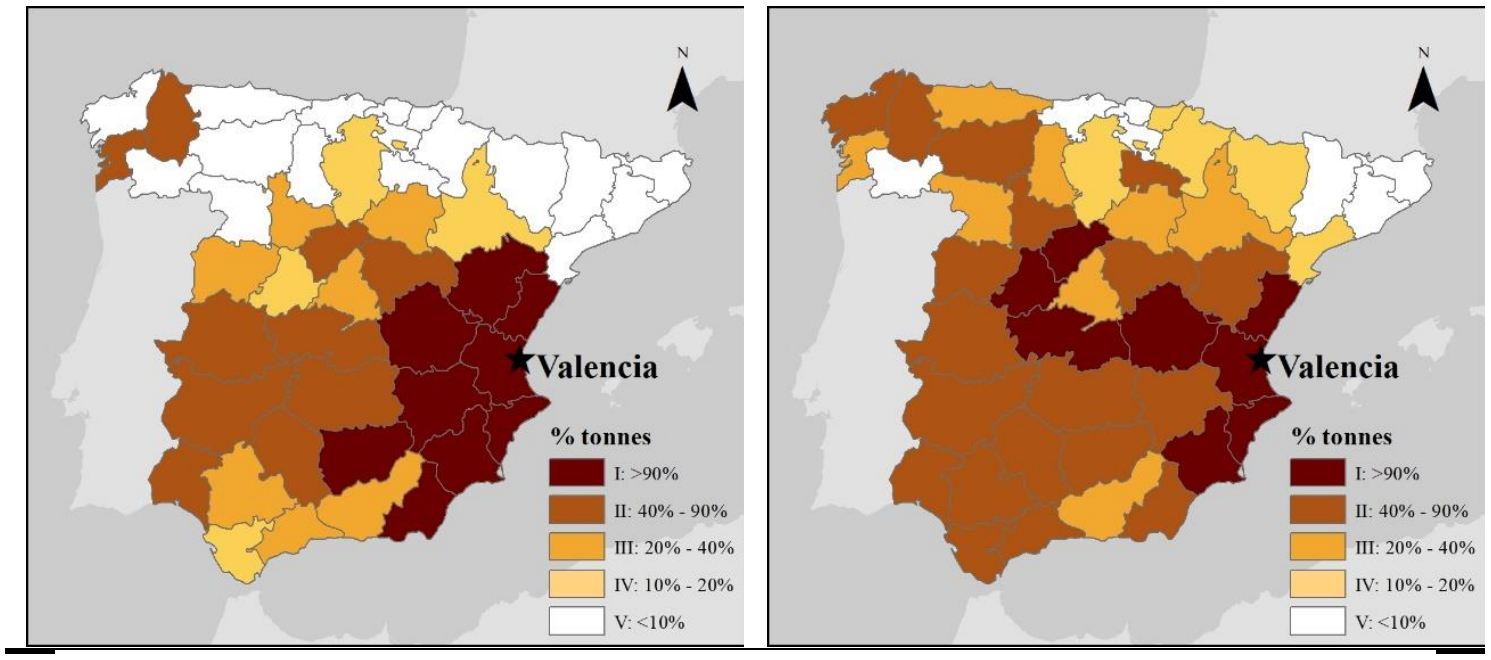

Figure A1. Port share in the provincial export flows (in tonnes) to America (20002015).

Source: authors' own elaboration based on data from the Foreign Trade Statistics of the Customs and Excise Duties Department of the Spanish Tax Agency (2017) 


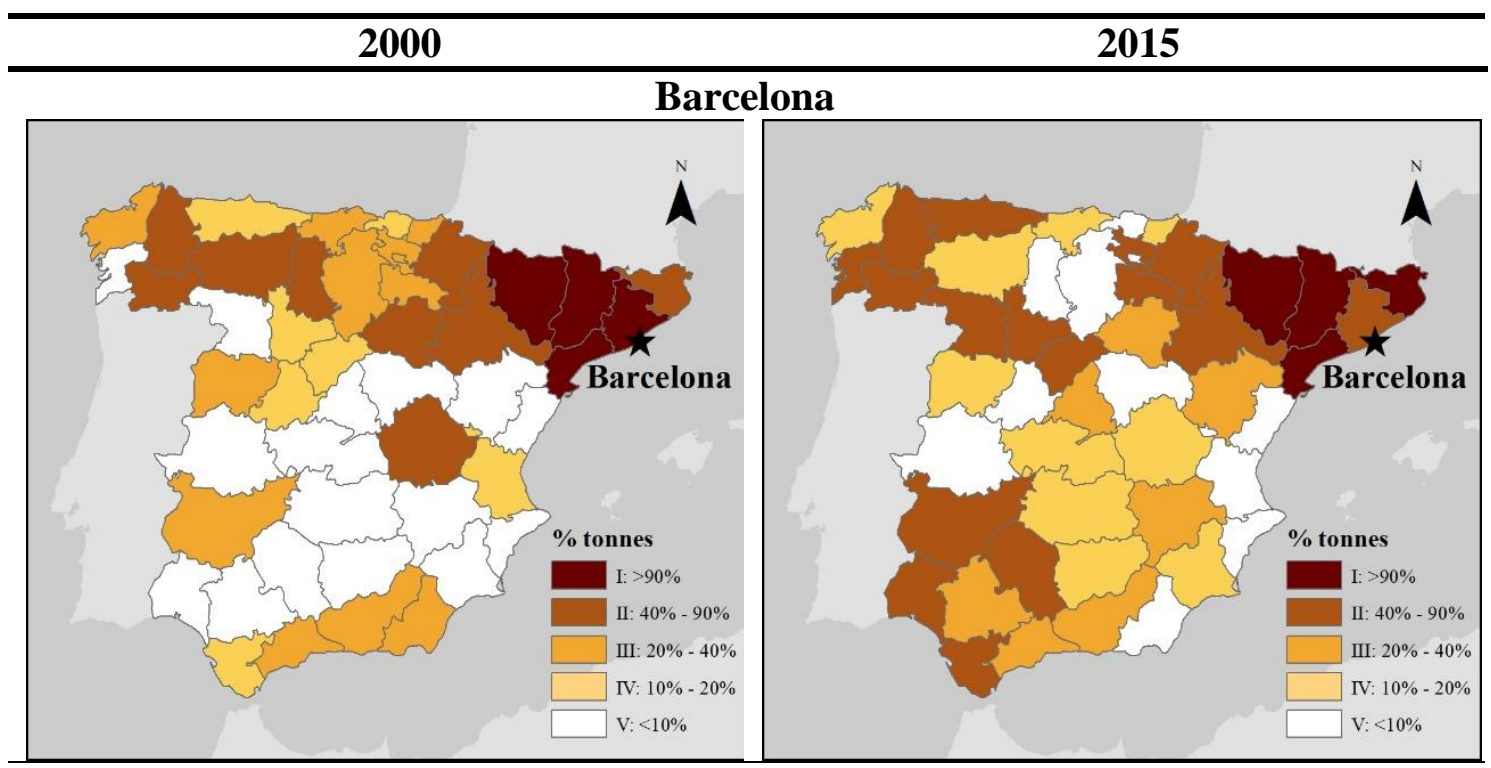

Bilbao

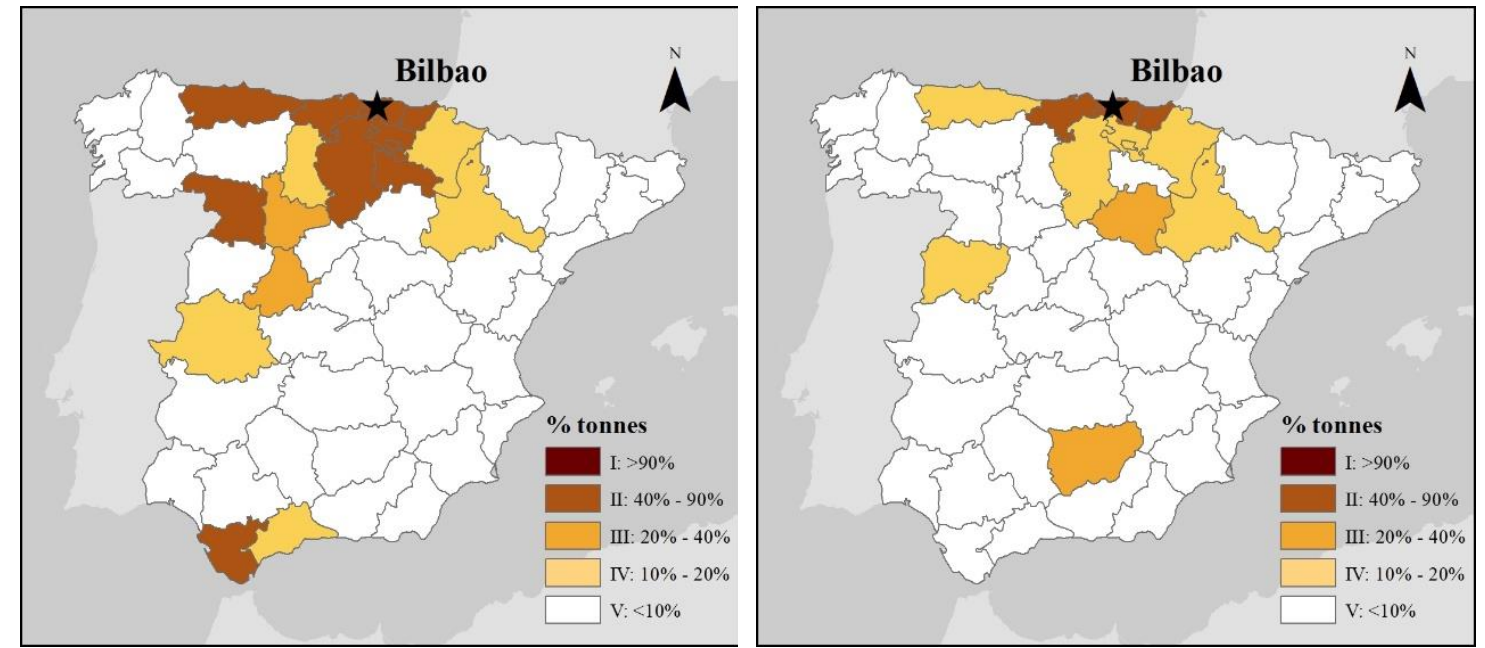

Valencia

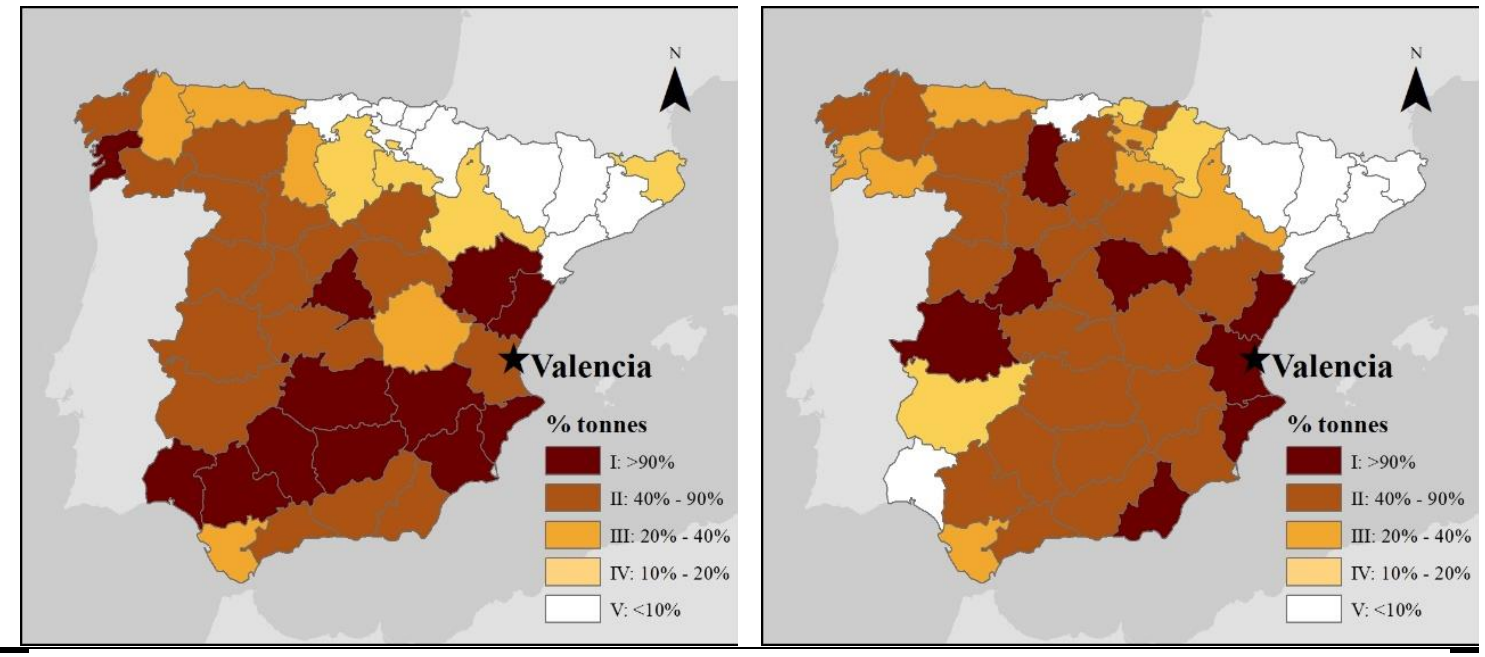

Figure A2. Port share in the provincial export flows (in tonnes) to Asia (2000-2015).

Source: authors' own elaboration based on data from the Foreign Trade Statistics of the Customs and Excise Duties Department of the Spanish Tax Agency (2017) 


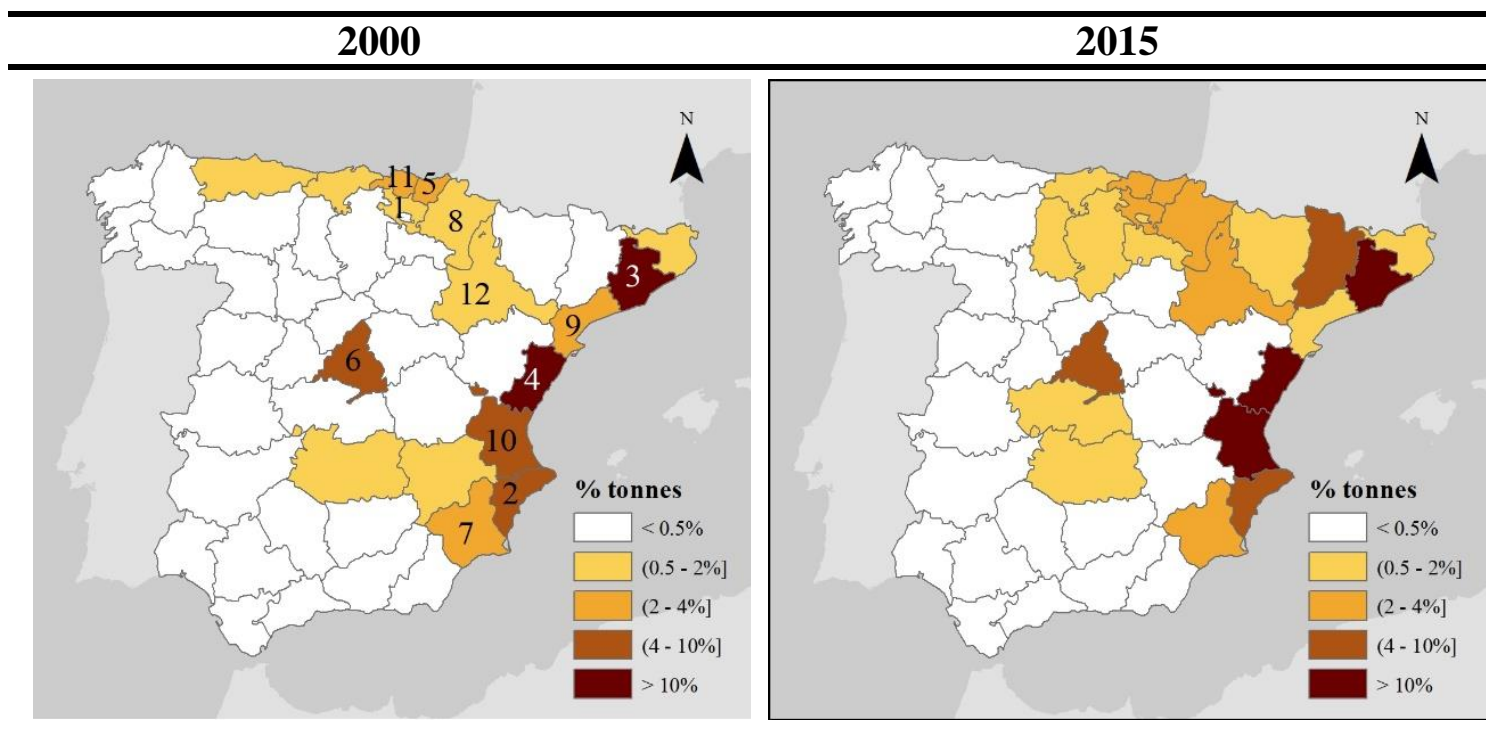

Figure A3. Provincial share in export flows generation (in tonnes) to Asia and America (2000-2015).

Source: authors' own elaboration based on data from the Foreign Trade Statistics of the Customs and Excise Duties Department of the Spanish Tax Agency (2017)

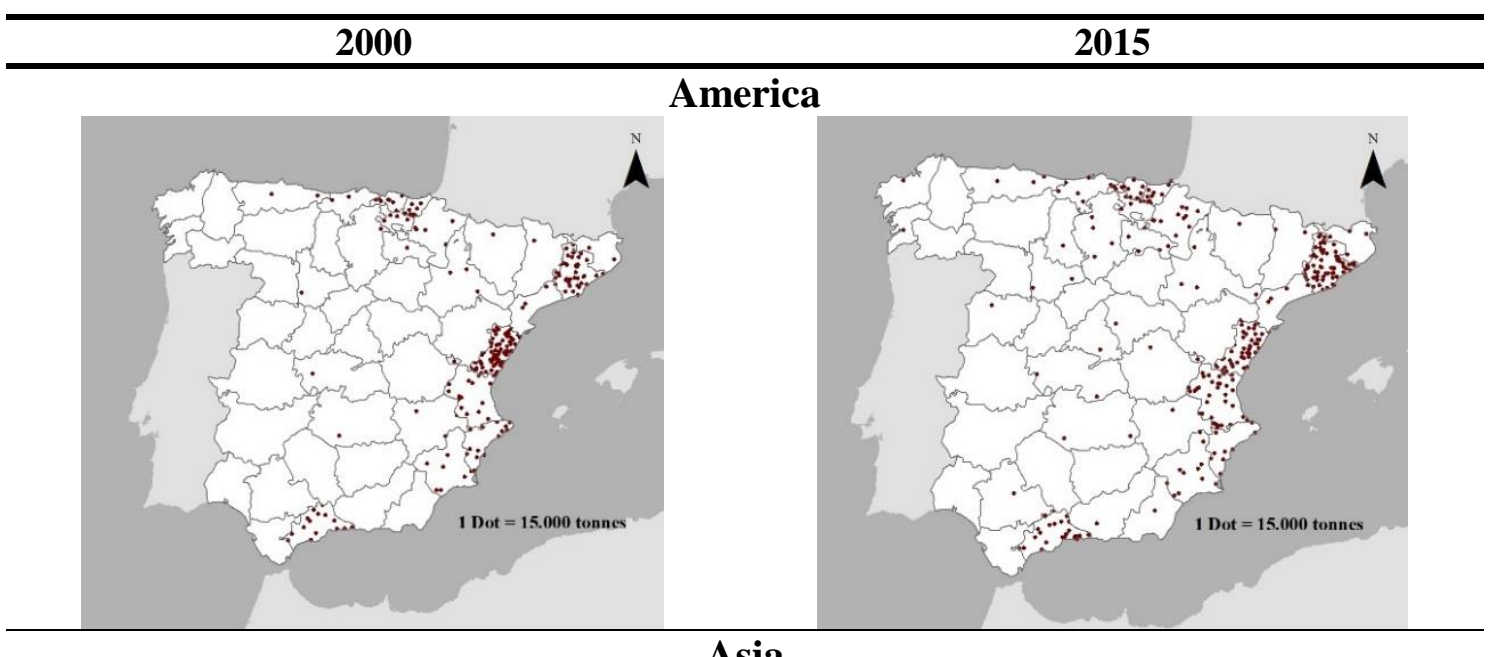

Asia
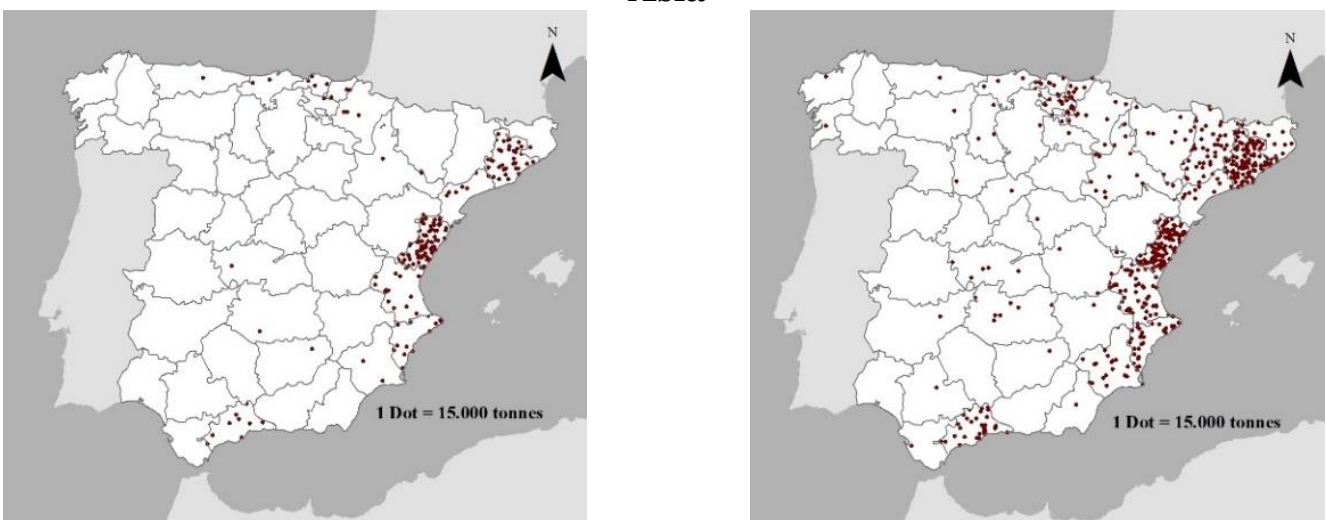

Figure A4. Dot density of provincial export flows (in tonnes), by continent (20002015).

Source: authors' own elaboration based on data from the Foreign Trade Statistics of the Customs and Excise Duties Department of the Spanish Tax Agency (2017). 
Table A1. Discrepancies concerning the provincial origin of the port traffic (observed minus estimated)

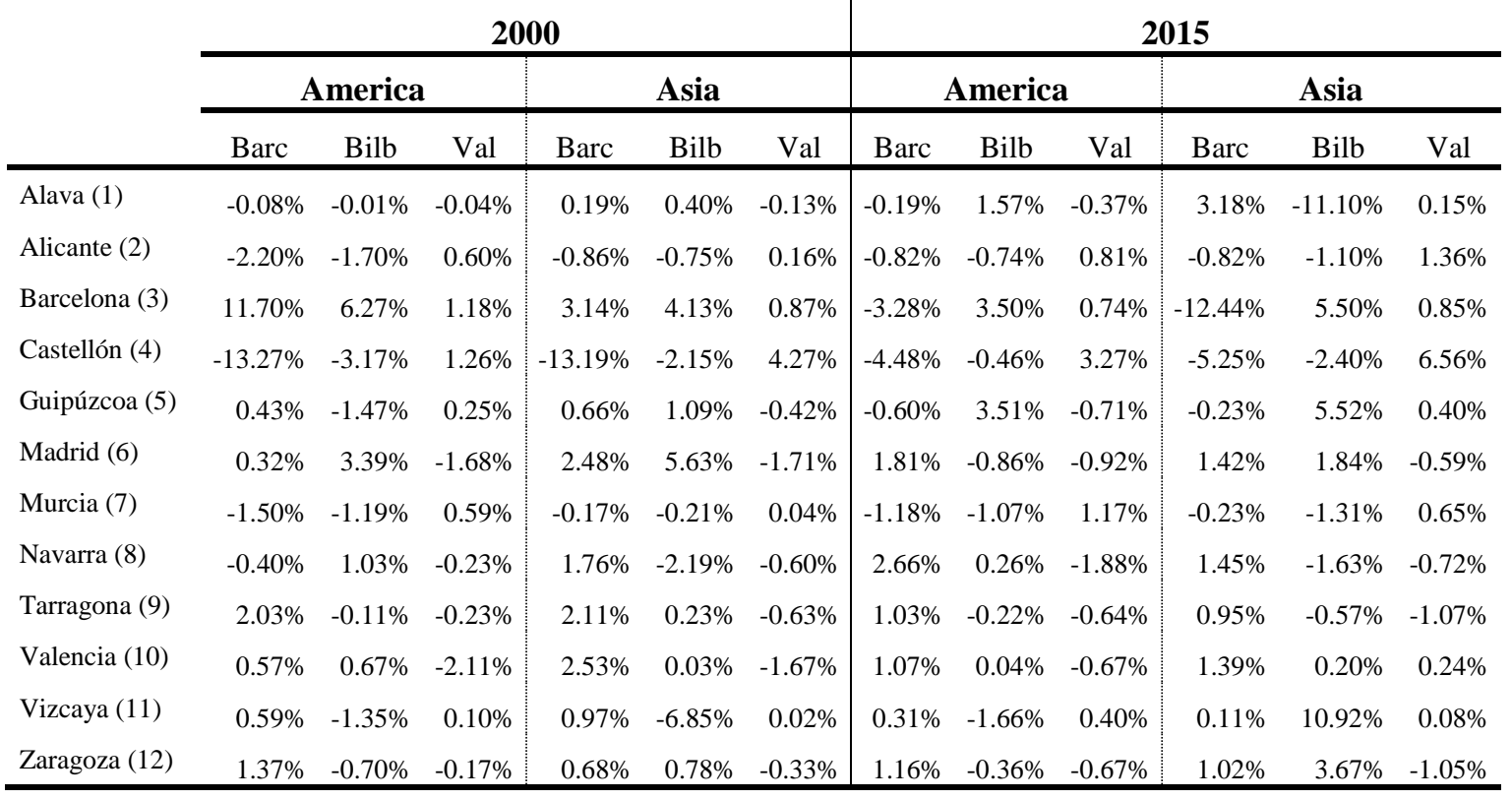

